\title{
Katolicka pedagogika seksualna
}

Pedagogika seksualna jest subdyscypliną pedagogiki, nauką o wychowaniu do miłości i seksualności. Jako nauka normatywna i empiryczna uwzględnia dorobek nauk pomocniczych, podejmuje badania rzeczywistości wychowawczej, tworzy teorie, a także formułuje prawa oraz ustala zasady, metody i formy działalności wychowawczej, odnoszącej się do seksualności i aktywności seksualnej człowieka. Trzeba zgodzić się z opinią, że za wyodrębnieniem tej dziedziny przemawia kilka ważnych argumentów. Pierwszy - to przyjęcie, iż seksualność człowieka jest tak ważnym wymiarem jego psychofizycznej kondycji, że nie sposób jej nie dostrzegać w jego funkcjonowaniu. Drugi - będący konsekwencją tego pierwszego - to uznanie, iż seksuologia jest jedną z ważniejszych nauk pomocniczych pedagogiki' Należy jednak też uznać trzeci i czwarty istotny argument, uwzględniające odpowiednio duchowy wymiar intymnych relacji seksualnych oraz prymat wychowania do życia w rodzinie, które mają swoje źródło w miłości

1 Z. Izdebski, Pedagogika seksualna, w: Encyklopedia pedagogiczna XXI wieku, red. T. Pilch, t. 4, Warszawa 2005, s. 251. 
małżeńskiej i rodzinnej ${ }^{2}$. W liberalnym podejściu często przekazuje się niepełny obraz ludzkiej seksualności, a edukację seksualną traktuje tylko jako uświadomienie $\mathrm{w}$ zakresie różnych zachowań seksualnych ${ }^{3}$. Funkcjonuje też wiele fałszywych mitów na temat chrześcijańskiej edukacji seksualnej ${ }^{4}$. Fryderyk Nietzsche np. uważał, że „chrześcijaństwo jakby dało erosowi do picia truciznę, a chociaż z jej powodu nie umarło, przerodziło się w wadę" „W ten sposób filozof niemiecki wyraża bardzo rozpowszechnione spostrzeżenie: czy Kościół swymi przykazaniami i zakazami nie czyni gorzkim tego, co w życiu jest najpiękniejsze? Czy nie stawia znaków zakazu właśnie tam, gdzie radość zamierzona dla nas przez Stwórcę ofiarowuje nam szczęście, które pozwala nam zasmakować coś z Boskości?” - pyta Benedykt XVI'. Papieskie pytania pozostają wyzwaniem, na które warto poszukiwać odpowiedzi w obrębie badań teologicznych i pedagogicznych.

\section{Seksualność w Piśmie Świętym}

Pismo Święte jest dziełem natchnionym, napisanym przez wielu autorów w bardzo złożonym kontekście społeczno-kulturowym i religijnym. Barwny i zróżnicowany język przekazu jest często niezrozumiały dla współczesnego odbiorcy. Podobnie wielość gatunków i form literackich domaga się specjalistycznej wiedzy filologicznej, historyczno-krytycznej, a przede wszystkim teologicznej. Dlatego też powierzchowna lektura nie pozwala dostrzec $\mathrm{w}$ nich pewnych aktualnych tematów związanych z życiem

2 Uczeni zajmujący się pedagogiką rodziny oraz nauką o rodzinie prowadzą systematyczne badania w tym obszarze wychowania, socjalizacji i edukacji; formułują prawa oraz ustalają zasady, metody i formy działalności wychowawczej, zgodne z właściwymi sobie antropologią, aksjologią, etyką oraz prawem. W polskim systemie oświaty i wychowania od 1999 roku funkcjonuje przedmiot „Wychowanie do życia w rodzinie”, który w praktyce realizuje założenia wychowania seksualnego typu A. Por. Wędrując ku dorosłości. Wychowanie do życia $w$ rodzinie. Program nauczania, red. T. Król, Kraków 2017; Zanim wybierzesz... Przygotowanie do życia $w$ rodzinie. Podstawy wychowania seksualnego, red. M. i W. Grabowscy, A. i M. Niemyscy, M. i P. Wołochowiczowie, Warszawa 1992.

3 S. Sławiński, Wychowanie seksualne czy wychowanie do miłości, w: Wychowanie potrzeba dziecka - zadanie domu i szkoły, red. E. Ozimek, Poznań 1999, s. 51-59.

4 Por. J. McDowell, Mity edukacji seksualnej, tłum. B. Kośmider, Warszawa 2000.

5 F. Nietzsche, Jenseits von Gut und Böse, München 1954, s. 168.

6 Por. Benedykt XVI, Encyklika Deus caritas est, 3. 
małżeńskim czy rodzinnym. Trzeba pamiętać, że Biblia nie jest podręcznikiem biologii, medycyny czy relacji społecznych, a jej autorzy często posługują się obrazem czy metaforą w celu opisania np. narządów płciowych lub aktu seksualnego.

Pojawiają się badacze, którzy podejmują trud odczytania wybranych tekstów Biblii nt. płciowości i seksualności zarówno w kontekście ich społeczno-kulturowego sensu, jak i czysto filologicznego i teologicznego znaczenia $^{7}$. Sięgając do pozornie niezrozumiałych wersetów dotyczących ludzkiej seksualności, warto zajrzeć do słowników symboliki biblijnej i fachowych opracowań, by dowiedzieć się, że np. „poznać” oznaczało w języku hebrajskim także „uprawiać seks” (por. Rdz 4,1.17.25; 1 Sm 1,19), „stopy” mogą być synonimem genitaliów, a gdy ktoś „poszedł okryć sobie nogi”, oznacza, że załatwiał potrzeby fizjologiczne (por. Sdz 3,24 czy 1 Sm 24,4). Otwarte pozostaje także pytanie: na czym polegał grzech sodomicki - na współżyciu „niezgodnym z naturą" czy też złej „polityce społecznej” (Rdz 19,5)?

Według niektórych egzegetów Księga Ezechiela szokuje nieobyczajnym (wręcz pornograficznym) językiem (por. Ez 16,7-63), a nierząd, prostytucja i seks jest obecny w wielu miejscach Biblii (por. Pwt 24,1; Kpł 18; Mt 5,32; 19,9; Dz 15,20; 1 Kor 5,1; 6,9; Ap 2,14.20-21; 17,2). Zupełnie inaczej intymność małżeńskich relacji oddaje opowiadanie o młodym Tobiaszu i Sarze, którzy zanim połączyli się w akcie małżeńskim, wcześniej przez trzy noce - po formalnych zaślubinach - oddali się wspólnej modlitwie (por. Tb 8,4-5; 6,18) ${ }^{8}$. Natomiast Księga Pieśni nad Pieśniami zachowała najwięcej obrazów i symboliki mówiących o subtelnościach współżycia seksualnego oblubieńców. To hymn o kobiecym i męskim ciele, o ich pięknie, godności i intymności wzajemnych relacji. Autor biblijny przeżywa swoją seksualność tak samo jak każdy inny człowiek, a dopiero właściwa interpretacja pomaga nam dostrzec pełny sens tekstów Pieśni nad Pieśniami ${ }^{9}$. Jest

7 Por. J. Kułaczkowski, Biblijne zasady wychowania rodzinnego w świetle Księgi Syracha, Rzeszów 1998; M. Babik, Słownik biblijny. Małżeństwo - rodzina - seksualność, Kraków 2009.

8 O trzech nocach modlitwy nowożeńców wspomina Wulgata św. Hieronima i komentarz do Biblii Jerozolimskiej; Biblia Jerozolimska, Poznań 2006, s. 550.

9 Poemat należy do ksiąg mądrościowych, a genezy księgi można szukać w uroczystościach towarzyszących ceremonii ślubnej (por. Jr 7,34; 16,9; Ps 45). Por. G. Ravasi, Pieśń nad pieśniami... jak pieczęć na twoim sercu, tłum. K. Stopa, Kraków 2005; J. Dillow, P. i L. Pintus, Rozpalona miłość. Jak rozwijać małżeńską intymność w oparciu o „Pieśń nad pieśniami” Salomona, tłum. G. Kożusznik, Ustroń 2005, s. 316-323. 
to zbiór poematów o wzajemnej miłości oblubieńca i oblubienicy, w którym nie brak czułości, namiętności, a nawet erotyki: „Postać twoja wysmukła jak palma ${ }^{10}$, a piersi twe jak grona winne. Rzekłem: wespnę się na palmę, pochwycę gałązki jej owocem brzemienne. Tak! Piersi twe niech [mi] będą jako grona winne, a tchnienie twe jak zapach jabłek. Usta twoje jak wino wyborne, które spływa mi po podniebieniu, zwilżając wargi i zęby"11.

Erotyka Pieśni nad Pieśniami jest erotyką pozytywną, natomiast Księgi Przysłów - negatywną, tzn. skierowaną przeciwko nadużyciom w sferze seksualnej albo też, ogólnie mówiąc, przeciw każdemu nieuporządkowaniu: „Bo lampą jest nakaz, a światłem Prawo, drogą do życia - upomnienie, nagana. One cię strzegą przed złą kobietą, przed obcą, choć język ma gładki: jej wdzięków niech serce twoje nie pragnie, powiekami jej nie daj się złowić, bo nierządnicy wystarczy kęs chleba, zamężna zaś czyha na cenne życie. Czy schowa kto ogień w zanadrzu, by nie zajęły się jego szaty? Czy kto pójdzie po węglach ognistych, a stóp nie poparzy?”12.

Kontynuacją myśli Pieśni nad Pieśniami w Nowym Testamencie może być zbiór zasad życia małżeńskiego i rodzinnego ${ }^{13}$ oraz tzw. Hymn o miłości, w którym miłość ukazana jest jako najdoskonalsza droga, „przewyższająca wszystkie inne"14. Hymn doczekał się wielu interpretacji egzegetycznych, literackich i poetyckich. Do zgłębiania jego treści zachęcali: Jan Paweł II ${ }^{15}$, Benedykt XVI ${ }^{16}$, a ostatnio Franciszek ${ }^{17}$.

10 Trzy kobiety w Biblii noszą imię Tamar - „palma”, która jest symbolem kobiecego piękna. Por. Rdz 38,6; 2 Sm 13,1; 14,27.

11 Pnp 7,8-10. Wnikliwą analizę fragmentów Pieśni nad pieśniami oraz Księgi Tobiasza przedstawił Jan Paweł II w cyklu katechez rzymskich. Por. Jan Paweł II, „Mężczyzną i niewiastą stworzył ich”. Odkupienie ciała a sakramentalność małżeństwa, Watykan 1986, s. 419-457.

12 Prz 6,23-28; Por. Ps 45; Ps 45 reprezentuje „pozytywne” ujęcie - „królewską pieśń weselną” (BT), „pieśń zakochanych” (BP), albo „Pieśń nad pieśniami w miniaturze”. Por. G. Ravasi, Psalmy, cz. 2, tłum. K. Stopa, Kraków 2007, s. 219-260.

13 Por. Ef 5,22-32.

14 M. Rosik, Pierwszy List do Koryntian, Częstochowa 2009 (Nowy Komentarz Biblijny. Nowy Testament, VII), s. 425-435; J. Jaromin, Analiza lingwistyczna „Hymnu o miłości” (1 Kor 13,1-13), w: Jak śmierć potężna jest miłość. Księga pamiątkowa ku czci Księdza Profesora Juliana Warzechy SAC (1944-2009), red. W. Chrostowski, Ząbki 2009, s. 127-140; J. Kochel, Duchowa pedagogia miłości, Poznań 2018, s. 54-65.

15 Jan Paweł II, Encyklika Dives et Misericordia, 13-14.

16 Benedykt XVI, Encyklika Deus caritas est, 34; Benedykt XVI, Adhortacja apostolska Verbum Domini, 103.

17 Franciszek, Adhortacja apostolska Amoris laetitia, 89-119. 
Benedykt XVI w adhortacji Verbum Domini zachęcał do budowania osobistej więzi ze świętymi Pismami, do ich interpretacji w liturgii i katechezie, a także wnikliwych badań naukowych, aby „Biblia nie była słowem z przeszłości, lecz słowem żywym i aktualnym”18. W ostatnim czasie kilku autorów - mniej czy bardziej udanie - podjęło odważne próby wydobycia tego, co Biblia mówi o seksualności. Są to popularne opracowania, które pragną dotrzeć do jak najszerszego grona czytelników, by interpretować i aktualizować wielokrotnie powtarzane fundamentalne biblijne przesłanie: „Bądźcie płodni i rozmnażajcie się, abyście zaludnili ziemię i uczynili ją sobie poddaną..." (Rdz 1,28; por. 8,17; 9,1; Ps 8,6-9; Syr 17,2-4; Mdr 9,2; 10,2; Jk 3,7).

Michael D. Coogan, ceniony amerykański biblista, rozważa kwestie seksu w Biblii, zwłaszcza w Starym Testamencie. Nie unika tematów trudnych i kontrowersyjnych, np. biblijnych wzmianek o jednopłciowych związkach, przekonując, że Pisma Świętego nie można wykorzystywać jako narzędzia skierowanego przeciwko osobom LGBT ${ }^{19}$. Inny biblista, Michael Pearl, zabiera swych czytelników w odświeżającą podróż przez biblijne teksty, przyglądając się z bliska tej najsilniejszej z namiętności, jaką Bóg kiedykolwiek stworzył. Podróż ta uwolni czytelnika od fałszywego poczucia winy, pruderii i zahamowań. Autor przekonuje: „Nadszedł czas, aby chrześcijańskie pary małżeńskie odebrały z powrotem to, co im zagarnięto: ich ziemię obiecaną, i na co dzień cieszyły się świętym darem seksualnych przyjemności"20.

Z kolei krytyczne poglądy prezentuje Uta Ranke-Heinemann, która mierzy się z kilkoma istotnymi pytaniami, np. dlaczego Kościół katolicki - od zarania papiestwa po dziś dzień - tak bardzo skupia się na płciowości człowieka? Dlaczego stawia na piedestale Maryję, a resztę kobiet uznaje za „źródło nieczystości"? Dlaczego za wszelką cenę chce kontrolować, jak, gdzie i w jaki sposób ludzie uprawiają seks?

Ta niemiecka profesor teologii, uczennica Rudolfa Bultmanna ${ }^{21}$, przekonuje swoich czytelników, że niechęć wobec cielesnej rozkoszy i rygorystyczne

\footnotetext{
18 Benedykt XVI, Adhortacja apostolska Verbum Domini, 5.

19 Por. M. D. Coogan, Bóg i seks. Co naprawdę mówi Biblia, tłum. A. Onysymow, Warszawa 2011.

20 M. Pearl, Seks (nie)zakazany owoc Biblii, tłum. G. Ciecieląg, Warszawa 2011, s. 13.

21 Prof. Ranke-Heinemann za krytykę Kościoła katolickiego oraz zawężanie dziewictwa Maryi wyłącznie do pojęcia czysto teologicznego i zaprzeczanie dogmatowi, że matka Jezusa pozostała także biologicznie dziewicą, została pozbawiona katedry teologii w Duisburgu i Essen. W 1987 roku objęła niezależną od Kościoła Katedrę Historii Religii i kontynu-
} 
poglądy na temat seksualności nie od razu stały się głównym orężem Kościoła w walce z grzechem. Czy Kościół rzeczywiście uznał, że wszystkie akty seksualne (również te małżeńskie) są w jakiś sposób „zanieczyszczone”, co miało wpłynąć na jego stosunek do kobiet? Czy naprawdę Kościół był wobec kobiet wrogi - od nadania niejasnego statusu i obłożenia swoistym „tabu” kobiet krwawiących i ciężarnych aż do rozpalenia stosów dla tych oskarżonych o czary i konszachty z diabłem? Autorka przygląda się tym aktom przemocy i niechęci, dociekając ich przyczyn i wyciągając jednoznacznie krytyczne wnioski.

Prawdą objawioną jest to, że Bóg obdarował ludzi wspaniałym darem seksualności (płciowości) i chce, by człowiek był za niego odpowiedzialny, by się o niego troszczył i pielęgnował. Seksualność to pozytywna siła, zorientowana ku dojrzałości osób, ale sama dla siebie jest etycznie i estetycznie bez właściwości ${ }^{22}$. To konkretny człowiek wpływa na wartość moralną aktu seksualnego. Temat seksualności i miłości erotycznej w Biblii nie może więc budzić zdumienia. Jest tam obecny i fachowo omawiany przez teologów biblijnych $^{23}$ oraz oficjalne nauczanie Kościoła ${ }^{24}$. Z kolei źródła biblijne inspirują autorów w różnych okresach dziejów ludzkości, by podejmowali temat seksualności $\mathrm{w}$ ramach innych dziedzin nauki ${ }^{25}$ oraz poszukiwali

owała swoją krytykę oficjalnego nauczania Kościoła. Por. U. Ranke-Heinemann, Eunuchen für das Himmelreich. Katholische Kirche und Sexualität von Jesus bis Benedikt XVI, Hamburg 1988 (wyd. pol. Eunuchy do raju. Kościół katolicki a seksualizm, tłum. M. Zeller, Gdynia 2003 oraz Seks. Odwieczny problem Kościoła, tłum. S. Lipnicki, U. Szymanderska, M. Zeller, Warszawa 2016); Neinund Amen. Mein Abschied vom traditionellen Christentum, Hamburg 1992 (wyd. pol. Nie i amen, tłum. K. Teoplitz, Gdynia 1994).

22 M. I. Rupnik, S. Averincev, Adam i jego żebro. Duchowość miłości małżeńskiej, tłum. B. Żukowska, Kraków 2009, s. 95-102.

23 J. Chmiel, Siedem spojrzeń na płciowość w Biblii, „Ruch Biblijny i Liturgiczny” 50/1 (1997), s. 28-35; K. Wiśniewski, Boski rodowód miłości erotycznej. Teologiczna refleksja o Trójcy Świętej i człowieku, „Collectanea Theologica” 76 (2006) nr 4, s. 47-79; M. Wojciechowski, Etyka Biblii, Kraków 2009, s. 69.

24 Najnowszy dokument Papieskiej Komisji Biblijnej Che cosa è l'uomo? (Czym jest człowiek? Wprowadzenie (droga) do antropologii biblijnej) rozwija temat antropologicznego aspektu miłości pomiędzy mężczyzną a kobietą (nr 158-198). Por. Pontificia Commissione Biblica. Che cosa è l'uomo? (Sal 8,5). Unitinerario di antopologiabiblica, Città del Vaticano 2019.

25 Por. Miłość i seks $w$ kulturach Wschodu starożytnego, red. K. Szarzyńska i in., Warszawa 1996; A. Zwoliński, Seksualność w relacjach społecznych, Kraków 2006; A. Giddens, Przemiany intymności. Seksualność, miłość i erotyzm we współczesnych społeczeństwach, tłum. A. Szulżycka, Warszawa 2006; R. Mazo Karras, Seksualność w średniowiecznej Europie, tłum. A. Bugaj, Warszawa 2012; I. Primoratz, Filozofia seksu, tłum. J. Klimczyk, Warszawa 2012; 
właściwej odpowiedzi na pytania: jak rozumieć fenomen seksualności we współczesnym świecie? Jak wykorzystać potencjał tej sfery życia dla integralnego rozwoju człowieka? Jak odnosi się do niego teologia i pedagogika?

\section{Teologia ciała}

„Czarna legenda” o negatywnej relacji Kościoła do seksualności jest wciąż rozpowszechniana w środowiskach liberalnych i przychylnych im środkach społecznego przekazu. Najlepszą odpowiedzią na powtarzane slogany okazało się pozytywne przesłanie teologii (pedagogia ciała) Karola Wojtyły - Jana Pawła II. Tematyka godności osoby ludzkiej, miłości i odpowiedzialności, miłości małżeńskiej i rodzinnej oraz seksualności ludzkiej towarzyszyła mu od czasów krakowskich poprzez wnikliwe studium filozofii i etyki na Katolickim Uniwersytecie Lubelskim, aż po długoletni pontyfikat (1978-2005), w którym szerzył on koncepcję „cywilizacji życia i miłości”26. Jako papież zaproponował wiernym Kościoła cykl stu trzydziestu katechez środowych na temat teologii ciała i sakramentalności małżeństwa (od 5 listopada 1979 do 28 listopada 1984 roku) ${ }^{27}$. Kwestia ludzkiej miłości, a dokładniej - spotkania osób poprzez miłość, zwłaszcza miłość małżeńską i rodzinną, od samego początku była obecna w nauczaniu papieża Wojtyły ${ }^{28}$. Po zakończeniu specjalnego synodu biskupów, który miał miejsce w Rzymie od 26 września do 25 października 1980 roku, papież opublikował adhortację apostolską Familiaris consortio o zadaniach rodziny chrześcijańskiej w świecie współczesnym ${ }^{29}$.

R. Tannahill, Historia seksu, tłum. G. Woźniak, Warszawa 2013; M. Komorowska-Pudło, Seksualność młodzieży XX i XXI wieku, Kraków 2013.

26 J. Nagórny, Cywilizacja miłości wobec współczesnych zagrożeń cywilizacyjnych, w: Przyszłość cywilizacji Zachodu, red. P. Jaroszyński i in., Lublin 2003 s. 57-89; W. Seremak, Cywilizacja miłości, w: Leksykon duchowości katolickiej, red. M. Chmielewski, Lublin-Kraków 2002, s. 154-156; K. Majdański, W służbie prawdzie o rodzinie. Prawda o człowieku, rodzinie i cywilizacji, red. B. Bassa, E. Osewska, J. Stala, Kraków 2019, s. 163-313.

27 Por. Jan Paweł II, „Mężczyzna i niewiasta stworzył ich”, dz. cyt.

28 Por. A. Najda, Stworzeni z miłości: wokót Jana Pawła II teologii ciała, Warszawa 2010; R. Skrzypczak, Wiara i seks. Jan Paweł II o małżeństwie i rodzinie, Kraków 2015.

29 Por. Jan Paweł II, Adhortacja apostolska Familiaris consortio, Watykan 1981. 
Zarówno zbiór katechez Mężczyzna i niewiasta stworzył ich, jak i posynodalna adhortacja apostolska Familiaris Consortio, obficie czerpią ze źródła biblijnego. Proponowana przez św. Jana Pawła II teologia/pedagogia ciała oraz kultura życia płciowego (seksualnego) jest rzeczywiście czymś, za czym tęskni współczesny młody człowiek. Ma rację amerykański biograf i popularyzator myśli św. Jana Pawła II - George Weigel - który przekonuje, że właśnie taka teologia i pedagogia są „bombą zegarową z opóźnionym zapłonem", która prędzej czy później wybuchnie ${ }^{30}$.

Popularność i nośność teologii ciała wyraźnie zaznaczyła się w świecie anglosaskim ${ }^{31}$. W środowisku tym odkrywana jest jako coś nowego, świeżego, inspirującego ${ }^{32}$. Spojrzenie papieża $z$ Polski inspiruje młodych do innego, pozytywnego spojrzenia na seksualność człowieka.

„Jan Paweł II nigdy nie wychodził od zakazów. Interesowała go jak najbardziej kompleksowa, pełna wizja człowieka. Koncentrował się na jak najgłębszym poznaniu człowieka od strony tajemnicy osoby. Także na poznaniu człowieka jako mężczyzny i kobiety. Interesowały go szanse zbudowania jak najbardziej trwałej oraz satysfakcjonującej relacji między ludźmi, która pozwala rozwijać człowieka, nasycać go wartościami. Dlatego też od samego początku zwracał uwagę na ludzką miłość. Na to, jakie warunki muszą być spełnione, żeby miłość była trwała, uszczęśliwiała ludzi, tworzyła związek trwały, wierny, ale także stawała się podstawą do wybudowania - jak on sam

30 G. Weigel, Listy do młodego katolika, tłum. J. Franczak, Kraków 2006, s. 153-159; Por. Z. Nosowski, All You Need is Sex? Jak zmienia się współczesne rozumienie erotyki?, „Więź” 7-8 (597) (2008), s. 72-82.

31 Świadczy o tym nowe wydanie książki Miłość $i$ odpowiedzialność. Por. K. Wojtyła, Love and Responsibility, transl. by G. Ignatiuk, Boston 2013.

32 Potwierdzają to dokument Konferencji Episkopatu USA. Por. United States Conference of Catholic Bishops, Create in Me a Clean Heart: A Pastoral Response to Pornography (November 2015), Catholic Truth Society 2017; http://ccc.usccb.org/flipbooks/clean-heart/\# (26.11.2018) oraz publikacje: J. Kupczak, Dar i komunia. Teologia ciała w ujęciu Jana Pawła II, Kraków 2006; Y. Semen, Seksualność według Jana Pawła II, tłum. Z. Denkowska, J. Urbaniak, Poznań 2008; Ch. West, Teologia ciała dla początkujących. Podstawy rewolucji seksualnej Jana Pawła II, tłum. M. i J. Kaniewscy, Warszawa 2009; P. Kopycki, Elementarz teologii ciała według Jana Pawła II, Częstochowa 2013; J. Evert, Teologia jej ciała / teologia jego ciała, tłum. J. Kurdziel, Kraków 2014; R. Marczewski, Teologia ciała Jana Pawła II. W praktyce amerykańskiego Kościoła, Kraków 2015; M. Siemion, Seks według Jana Pawła II cię wyzwoli, Kraków 2016. 
mówił - najbardziej podstawowego środowiska osobotwórczego, jakim jest rodzina" - przekonywał Robert Skrzypczak ${ }^{33}$.

Prof. Karol Wojtyła już jako młody biskup w latach 60. rozwijał nauczanie na temat miłości i seksualności. W latach1959-1960 prowadził także wykłady na KUL dotyczące małżeństwa i rodziny. Wyjeżdżał z młodymi ludźmi na wakacje, przysłuchując się im, wchodząc w dialog, towarzysząc także narzeczonym i małżonkom. Z tego w 1960 roku narodziła się książka Miłość i odpowiedzialność, która została potem przetłumaczona na język francuski z przedmową Henri de Lubaca i dotarła do papieża Pawła VI. Istotny jest też jego wkład w dyskusję soborową na temat małżeństwa i rodziny. To był czas, kiedy Paweł VI przygotowywał encyklikę Humanae vitae dotyczącą ludzkiej płodności, a także etyki przekazu życia w małżeństwie. Encyklikę opublikowano w 1968 roku, a Karol Wojtyła został zaproszony przez papieża do grona ekspertów, którzy mieli przygotować bazę teoretyczną do powstania tej pracy. I właśnie kard. Wojtyła, jak się okazuje, należał do nielicznych osób, które wsparły Pawła VI w podejściu, jakie ten zademonstrował w encyklice Humanae vitae ${ }^{34}$.

Dokument Kościoła z 1968 roku o zasadach moralnych w dziedzinie seksualności i przekazywania życia ludzkiego potwierdził dotychczasowe nauczanie Kościoła, lecz w społeczności zlaicyzowanej, zwłaszcza mass mediach i niektórych środowiskach katolickich, wywołał niespotykaną do tej pory kontestację i nagonkę na ojca świętego. Po latach jego następca Jan Paweł II tak skomentował tę sytuację: „Powierzono [Pawłowi VI] ster w momencie, gdy wybuchła jedna $\mathrm{z}$ najgwałtowniejszych burz, jakie kiedykolwiek szarpały łodzią Piotrową, więc pilotował ją tak, jak się w takich wypadkach robi: lawirując, żeby łodzi nie przewrócić, ale nigdy nie tracąc

33 Por. ks. prof. Robert Skrzypczak, Bitwa o seksualność, www.fronda.pl/a/ks-prof-robert-skrzypczak-bitwa-o-seksualnosc,106002.html/ (23.03.2020). Propozycja pewnej syntezy na temat antropologii: K. Wojtyła, „Osoba i czyn” oraz inne studia antropologiczne, Lublin 1994; Por. J. Galarowicz, Człowiek jest osoba. Podstawy antropologii filozoficznej Karola Wojtyły, Kraków 1994; T. Styczeń, Comprendere l'uomo. La visione antropologica di Karol Wojtyła, Roma 2005; J. Miąso, Antropologia, wychowanie, miłość. Zarys antropologii wychowania Jana Pawła II, Rzeszów 2014; J. Kochel, Wprowadzenie do antropologii pedagogicznej. W kręgu pedagogiki katolickiej, Opole 2018, s. 36-42.

34 Paweł VI, Encyklika Humanae vitae, Szczecin 1986; Por. P. S. Gałuszka, Karol Wojtyła e „Humanae vitae”. Il contributo dell'Arcivescovo di Cracovia e del gruppo del teologi polacchi all'enciclica do Paolo VI, Siena 2018. 
z oczu gwiazdy przewodniej, którą chyba tylko on jeden chwilami dostrzegał wśród chmur"35.

Paweł VI przekonywał, że nie wolno dopuścić do oderwania się seksualności od miłości, a także wierności od małżeństwa: „Stosunki, przez które małżonkowie jednoczą się w sposób intymny i czysty, i przez które przekazuje się życie ludzkie są - jak to przypomniał niedawno Sobór - «uczciwe i godne» ${ }^{36}$. Nie przestają być moralnie poprawne, nawet gdyby przewidywano, że z przyczyn zupełnie niezależnych od woli małżonków będą niepłodne, ponieważ nie tracą swojego przeznaczenia do wyrażenia i umocnienia zespolenia małżonków. Wiadomo zresztą z doświadczenia, że nie każde zbliżenie małżeńskie prowadzi do zapoczątkowania nowego życia. Bóg bowiem tak mądrze ustalił naturalne prawa płodności i jej okresy, że już same przez się wprowadzają one przerwy między kolejnymi poczęciami. Jednakże Kościół, wzywając ludzi do przestrzegania nakazów prawa naturalnego, które objaśnia swoją niezmienną doktryną, naucza, że konieczną jest rzeczą, aby każdy akt małżeński zachował swoje wewnętrzne przeznaczenie do przekazywania życia ludzkiego" ${ }^{37}$.

Papież w istocie rzeczy stanął przede wszystkim w obronie prawa naturalnego: „Człowiek nie zdoła osiągnąć prawdziwego szczęścia, do którego tęskni całą swą istotą, inaczej, jak zachowując prawa, wszczepione w jego naturę przez Najwyższego Boga. Do praw tych powinien on odnosić się w duchu mądrości i miłości”38. Nauczanie papieskie na temat seksualności, etyki małżeńskiej i rodzinnej okazało się prorocze i dlatego zasługuje na przypomnienie, a nawet na swoistego rodzaju rehabilitację ${ }^{39}$. Jego zwieńczeniem było powołanie Papieskiego Komitetu ds. Rodziny (1973) oraz

35 Ważną rolę w powstaniu encykliki odegrał ówczesny metropolita krakowski Karol Wojtyła. Na prośbę Pawła VI utworzył wówczas w Krakowie specjalną komisję, która miała przygotować materiały do encykliki (tzw. „Memoriał krakowski”). Członek tej komisji, ks. Andrzej Bardecki, wspominał: „Wspólnie w szeregu spotkań przygotowaliśmy materiały, które kardynał Wojtyła przekazał Pawłowi VI. Kiedy porównywałem potem encyklikę «Humanae vitae» $\mathrm{z}$ naszymi materiałami, stwierdziłem, że co najmniej 60 proc. materiałów krakowskich weszło do encykliki”; Por. A. Frossard, «Nie lękajcie się!». Rozmowy z Janem Pawłem II, tłum. A. Turowiczowa, Watykan 1982, s. 213; A. Bujak, M. Rożek, Wojtyła, Wrocław 1997, s. 165.

36 Paweł VI, Konstytucja Gaudium et spes, 49.

37 Paweł VI, Encyklika Humanae vitae, 11.

38 Paweł VI, Encyklika Humanae vitae, 31.

39 Wnikliwą analizę wybranych fragmentów encykliki Humanae vitae przedstawił Jan Paweł II na zakończenie cyklu katechez rzymskich; Por. Jan Paweł II, „Mężczyzną i niewiastą stworzyt ich", dz. cyt., s. 459-499. 
opublikowanie deklaracji o niektórych zagadnieniach etyki seksualnej Persona humana ${ }^{40}$, za co zresztą - podobnie jak za Humanae vitae - spotkała go ostra krytyka ze strony środowisk liberalnych.

Kontynuacją swoistego „podążania pod prąd” w temacie właściwie rozumianej seksualności i miłości małżeńskiej było nauczanie moralne Jana Pawła II, a zwłaszcza jego adhortacja apostolska Familiaris Consortio o zadaniach rodziny chrześcijańskiej w świecie współczesnym. Papież Wojtyła przekonywał, że małżeństwo jest komunią miłości obojga małżonków, a poprzez sakrament jest też komunią małżonków z Bogiem.

„Miłość pomiędzy mężczyzną i kobietą w małżeństwie i, w formie pochodnej i rozszerzonej, miłość pomiędzy członkami tej samej rodziny - pomiędzy rodzicami i dziećmi, pomiędzy braćmi i siostrami, pomiędzy krewnymi i domownikami - jest ożywiona i podtrzymywana przez wewnętrzny, nieustający dynamizm, prowadzący rodzinę do coraz głębszej i mocniejszej komunii, która jest fundamentem i zasadą wspólnoty małżeńskiej i rodzinnej”- uczy Ojciec święty ${ }^{41}$.

Komunią osób jest też rodzina, wezwana do realizacji konkretnych zadań: tworzenia tej pierwszej i fundamentalnej wspólnoty, służba życiu, udziału w rozwoju społeczeństwa oraz w życiu i posłannictwie Kościoła.

„(...) płciowość, poprzez którą mężczyzna i kobieta oddają się sobie wzajemnie we właściwych i wyłącznych aktach małżeńskich, nie jest bynajmniej zjawiskiem czysto biologicznym, lecz dotyczy samej wewnętrznej istoty osoby ludzkiej jako takiej. Urzeczywistnia się ona w sposób prawdziwie ludzki tylko wtedy, gdy stanowi integralną część miłości, którą mężczyzna i kobieta wiążą się z sobą aż do śmierci. Całkowity dar z ciała byłby zakłamaniem, jeśliby nie był znakiem i owocem pełnego oddania osobowego, w którym jest obecna cała osoba, również w swym wymiarze doczesnym" 42 .

Jedność mężczyzny i kobiety ma znaczenie głębsze niż tylko samo doświadczenie pociągu seksualnego związanego z płciowością. Wskazuje nam na pełnię, tj. duchowo-fizyczną, w której wszystkie sfery małżonków powinny ze sobą współistnieć i integrować się. Jest ona „bez wątpienia tą jednością, która wyraża się i urzeczywistnia w akcie małżeńskim"43. Zdaniem

40 Paweł VI, Deklaracja o niektórych zagadnieniach etyki seksualnej «Persona humana», „Acta Apostolicae Sedis” 68 (1976), s. 77-96.

41 Jan Paweł II, Adhortacja apostolska Familiaris consortio, 18.

42 Jan Paweł II, Adhortacja apostolska Familiaris consortio, 11.

43 Sobór Watykański II, Konstytucja Lumen gentium, 49. 
Jana Pawła II małżonkowie, jednocząc się ze sobą w akcie małżeńskim, odkrywają „za każdym razem i w sposób specjalny tajemnicę stworzenia, wracając w ten sposób do tego zjednoczenia w człowieczeństwie («ciało z mego ciała i kość z moich kości»), które pozwala im rozpoznać się wzajemnie, i jak za pierwszym razem, nazwać się po imieniu. To znaczy na nowo przeżyć w pewnym sensie pierwotną dziewiczą wartość człowieka, która wyłania się z tajemnicy jego samotności wobec Boga i wśród świata"44.

Niepodzielna jedność komunii małżeńskiej winna zmierzać „ku coraz głębszej więzi pomiędzy sobą na każdym poziomie: na poziomie związku ciał, charakterów, serc, umysłów i dążeń, związku duszy, ukazując w ten sposób Kościołowi i światu nową komunię miłości, jak dar łaski Chrystusowej" 45 . Stąd też podstawowym zadaniem małżeństwa i rodziny jest służba życiu oraz urzeczywistnianie pierwszego błogosławieństwa Stwórcy: „Bądźcie płodni i rozmnażajcie się, napełniajcie ziemię i podporządkowujecie ją sobie..." ${ }^{\prime 4}$.

Papież Jan Paweł II - w kontekście tego błogosławieństwa i pierwotnej jedności dwojga osób, aktu cielesnego mężczyzny i kobiety - uczy subtelnego rozróżniania: „Cielesność i płodność nie utożsamiają się bez reszty. Jakkolwiek bowiem ciało ludzkie w swej normalnej konstrukcji zawsze nosi w sobie znamiona płci, jest z natury męskie lub kobiece - to jednak fakt, że człowiek «jest ciałem», wchodzi w strukturę osobowego podmiotu w znaczeniu bardziej podstawowym niż fakt, że jest on w swej somatycznej konstrukcji, jako człowiek, mężczyzną lub kobietą"47.

\section{Dar seksualności}

Papież Wojtyła wytrwale przekonywał o znaczeniu pierwotnej nagości, wartości wstydu i intymności. Akt seksualny małżonków jest szczególnym

\footnotetext{
44 Jan Paweł II, „Mężczyznq i niewiastą stworzył ich”, dz. cyt., s. 33-45.

45 Jan Paweł II, Adhortacja apostolska Familiaris consortio, 19.

46 Rdz 1,28. Tłumaczenie wg nowego przekładu i komentarza; por. J. Lemański, Księga Rodzaju. Rozdziały 1 - 11, Częstochowa 2013, s. 136. 170-173 (Nowy Komentarz Biblijny. Stary Testament I/1).

47 Jan Paweł II, „Mężczyzna i niewiastą stworzył ich”, dz. cyt., s. 33.
} 
rodzajem „poznania” i to poznania bardzo intymnego i dogłębnego ${ }^{48}$. W śród wielu aspektów tajemnicy życia i współżycia istotne jest również papieskie wyjaśnienie greckiego terminu eros jako źródłosłowu tego, co „erotyczne” 49 . Przede wszystkim jednak trzeba pamiętać o katolickiej interpretacji aktu ludzkiego: „Płodność jest owocem i znakiem miłości małżeńskiej, żywym świadectwem pełnego oddania się małżonków" ${ }^{50}$.

Daru seksualności człowiek nie otrzymuje w gotowej i dojrzałej postaci, należy nauczyć się go pielęgnować, rozwijać dla własnego dobra oraz dla dobra innych ${ }^{51}$. Seksualnością rządzą bowiem pewne prawa biologiczne, psychologiczne, społeczno-kulturowe i religijne. Obowiązkiem człowieka jest najpierw je poznać i liczyć się z nimi - dopiero to gwarantuje pełne i dojrzałe korzystanie z owego daru. W przeciwnym razie może stać się on źródłem kryzysów czy kłótni oraz głębokich zranień, cierpień i lęków ${ }^{52}$.

48 Hebrajskie jāda wg Rdz 4,1 (por. 16,2.4; 38,16; 39,7) to szczególne źródło poznania drugiego człowieka. Jest ono doświadczeniem o najwyższym stopniu intymności, mianowicie zbliżenia (aktu) seksualnego; Por. J. Lemański, Księga Rodzaju, dz. cyt., s. 275.

49 Jan Paweł II, „Mężczyzną i niewiastą stworzył ich”, dz. cyt., s. 187-197. Benedykt XVI dokona ważnego porównania pomiędzy eros i agape, wskazując na różnice i jedność w pojmowaniu tych dwóch terminów. Por. Benedykt XVI, Encyklika Deus caritas est, 3-11. Franciszek pisze zaś o namiętnym i erotycznym wymiarze miłości małżonków, która „obejmuje dobro całego człowieka i dlatego może obdarzyć szczególną godnością możliwość ekspresji ciała i ducha, i uszlachetnić je jako elementy i szczególne znaki przyjaźni małżeńskiej”. Por. Paweł VI, Konstytucja Gaudium et spes, 49; Franciszek, Adhortacja apostolska Amoris laetitia, 142-152. Przestrzega też przed nadużyciami w sferze seksualnej - przemocą i manipulacjami. Por. Franciszek, Adhortacja apostolska Amoris laetitia, 153-157.

50 Jan Paweł II, Adhortacja apostolska Familiaris consortio, 28. Cały numer internetowego kwartalnika naukowego „Fides et Ratio” podejmuje omawianą tutaj problematykę płciowości, seksualności i odpowiedzialności; por. www.stowarzyszeniefidesetratio.pl/Presentations0/Fides2014-4.pdf/ oraz problematykę płodności i prokreacji; por. (24.03.2020).

51 Dużym wezwaniem jest rozmowa nt. współżycia seksualnego - aktu małżeńskiego; por. Akt małżeński. Szansa spotkania z Bogiem i wspótmałżonkiem. Rekolekcje dla małżeństw, CD - MP3, Kraków 2018.

52 Por. M. Braun-Gałkowska, Miłość aktywna. Psychiczne uwarunkowania powodzenia w małżeństwie, Warszawa 1980; J. Augustyn, Integracja seksualna. Przewodnik w poznawaniu i kształtowaniu własnej seksualności, Kraków 20196; M. B. Wojciszke, Psychologia miłości. Namiętność, intymność, zaangażowanie, Gdańsk 2000; W. Półtawska, Przygotowanie do małżeństwa, Kraków 2002; W. Półtawska, Eros et iuventus!, Częstochowa 2009; K. Meissner, Płciowość i czystość. Z problematyki życia seksualnego, Poznań 2004; K. Meissner, Psychologia płciowości, audiobook MP3, Poznań 2017; K. Meissner, Jeden plus jeden to jedność, audiobook MP3, Poznań 2017; J. Goleń, Wychowanie seksualne $w$ rodzinie. Studium pastoralne, Rzeszów 2006; M. Pilśniak, Krótka kołdra. O dialogu małżeńskim, Poznań 2010; M. Dziewiecki, 
Koncepcja odrzucająca cielesność (seksualność) lub wypaczona jej wizja - zakorzeniona w filozofii Platona (dualizm antropologiczny), a rozwijana przez gnostycyzm i inne błędne poglądy (np. jansenizm, rewolucję seksualna) - domagają się procesu „uzdrowienia” (korekty), wnikliwej analizy społeczno-kulturowej (wiedzy) ${ }^{53}$ oraz poszukiwania jej pogłębionej duchowości ${ }^{54}$. Pożądanie seksualne jest stricte ludzką sferą aktywności - to zjawisko przynależne wyłącznie ludziom, wymagające od nich wyznaczenia granic wyczucia „przyzwoitości”55. Domaga się rozumnej kontroli, właściwej edukacji oraz programów terapii uzależnień, takich jak Wolni, aby kochać56. Pozytywne ujęcie seksualności przekazuje katolicka etyka wychowania seksualnego ${ }^{57}$. To w niej ukryte jest przesłanie: ciało nie jest wrogiem, ciało jest czymś naturalnym i dobrym, tak samo jak cała seksualność człowieka. Nauka Kościoła jednoznacznie stwierdza, że ciało i dusza są jednością, i tylko w taki sposób można widzieć całego człowieka. Nasze ciało mówi nam, że pochodzimy od kogoś Innego i że jesteśmy powołani do relacji z kimś innym ${ }^{58}$. Ta relacja może realizować się $\mathrm{w}$ małżeństwie sakramentalnym, w którym małżonek wyraża swoją miłość (utożsamioną ze sferą duchową, nie tylko cielesną) poprzez ciało (por. Mt 19,1-5; Ef 5,21-32).

Współczesny pogląd na seksualność ewoluuje i podlega różnym wpływom społeczno-kulturowym, nie ulega jednak wątpliwości, że kształtowanie właściwych postaw wobec płciowości i sposobów realizacji potrzeb seksualnych należy do ważnych zadań wychowania w rodzinie, szkole i poprzez środki społecznego przekazu oraz samowychowania w tej sferze życia ludzkiego. Etyka seksualna uwzględnia biologiczne, psychologiczne i kulturowe

Problemy z seksualnością. Odpowiedzi na dylematy młodych chrześcijan, Kraków 2011; W. Zatorski, Kryzys małżeństwa?, Kraków 2018.

53 D. Ange, Twoje ciało stworzone do życia, tłum. J. Pleciński, Poznań, 1996, s. 16; Por. G. Kuby, Rewolucja genderowa. Nowa ideologia seksualności, Kraków 2007; G. Kuby, Globalna rewolucja seksualna. Likwidacja wolności w imię wolności, Kraków 2013; P. Mazurkiewicz, Dwie wieże i minaret, Warszawa 2017.

54 Por. R. Rolheiser, Duchowość seksualności, tłum. K. Tybinka, Kraków 2013.

55 R. Scruton, Pożądanie. Filozofia moralna życia erotycznego, tłum. T. Kuniński, Kraków 2009, s. 12.

56 Por. Uwolnić się od pornografii. Program „Wolni, aby kochać”, red. E. Jacquinet, tłum. A. Muszala, Kraków 2020.

57 Por. A. Marcol, Etyka życia seksualnego, Opole 1995; Wychowanie seksualne w rodzinie i szkole, red. K. Glombik, Opole 2010; Wychowanie do czystości - utopia czy zadanie, red. J. Kochel, Opole 2011.

58 Por. Katechizm Kościoła katolickiego, 357; 1711. 
postawy oraz sposoby realizacji płciowości właściwe osobie jako bytowi rozumnemu i wolnemu; nie ogranicza się jednak do opisu zwyczajów, rytów czy obrzędów seksualnych, lecz aspiruje do wyjaśnienia konkretnych powinności moralnych w sferze seksualnych przeżyć osoby ${ }^{59}$. Papieska Rada ds. Rodziny potwierdza, że ludzka płciowość (kobiecość i męskość) odnosi się do wewnętrznej istoty każdej osoby i jako taka osiąga swoje pełne znaczenie wtedy, gdy staje się wyrazem osobowego daru mężczyzny i kobiety ${ }^{60}$.

Bóg, który jest miłością (por. $1 \mathrm{~J}$ 4,8), wpisał w tożsamość kobiety i mężczyzny zdolność do miłowania, będącego jednocześnie zadaniem, dlatego można mówić o duchowym sposobie przeżywania seksualności, a płciowość ludzka nie jest nigdy faktem tylko fizyczno-psychicznym, lecz angażuje całą osobę, stąd brak miłości we wzajemnych relacjach seksualnych jest potraktowaniem człowieka jak rzecz: „Miłość we wzajemnych stosunkach pomiędzy ludźmi nie jest czymś gotowym. Jest ona naprzód zasadą czy też ideą, do której ludzie muszą niejako podciągnąć swe postępowanie, jeżeli chcą - czego chcieć powinni - uwolnić je od nastawienia użytkowego, czyli konsumpcyjnego (łac. consumere - zużywać) względem innych osób"61.

Istotna jest zatem stała formacja małżonków - wzajemne wychowywanie się przy pomocy spotkań i dialogu matżeńskiego ${ }^{62}$, kontaktu pomocowego w ramach duszpasterstwa rodzin bądź przy użyciu różnych form komunikacji - budowania relacji, np. małżeńskiej gry planszowej, która daje możliwość poznania zasad prawidłowej komunikacji, poznania różnic między kobietą a mężczyzną, budowania więzi małżeńskich poprzez rozmowę i zrozumienie ${ }^{63}$.

59 Por. K. Wiśniewska-Roszkowska, Seks i moralność, Warszawa 1988; B. Fraling, Sexualethik. Ein Versuch Aus Christlicher Sicht, Paderborn 1995; P. Góralczyk, Wychowawcza etyka seksualna, Ząbki 2000; Miłość, płciowość, płodność. Aktualne problemy etyki seksualnej, red. P. Morciniec, Opole 2007; I. Mroczkowski, Osoba i cielesność. Moralne aspekty teologii ciała, Płock 20082; T. Ślipko, Przedmałżeńska etyka seksualna, Kraków 2012.

60 Por. Papieska Rada ds. Rodziny. Ludzka płciowość, prawda i znaczenie. Wskazania dla wychowania $w$ rodzinie, www.kodr.pl/wp-content/uploads/2018/10ludzka_plciowosc_ prawda_i_znaczenie.pfd (10.03.2020).

61 K. Wojtyła, Miłość i odpowiedzialność, Lublin 1986, s. 31 n.

62 W ramach „Domowego Kościoła” (zob. Dialog małżeński, Kraków 2012; www. dk.oaza.pl (24.05.2018)) czy Wspólnoty Trudnych Małżeństw „Sychar” (www.sychar.org/ category/dialog-malzenski (17.01.2020)); Por. Przymierze małżeńskie, red. S. Bejnarowicz, Poznań 2014.

63 Planszowa gra małżeńska uczy: nieprzerywania sobie w rozmowie, skupienia się na jednym temacie, nazywania problemu, poruszania w bezpieczny sposób spraw trudnych 
W zakres obowiązków małżeńskich, obok poznania, poczęcia i zrodzenia potomstwa, wpisane jest konsekwentne wychowywanie do życia w miłości i rodzinie kolejnych pokoleń: „Wychowanie do miłości pojętej jako dar z siebie stanowi nieodzowną przesłankę dla rodziców wezwanych do przekazywania dzieciom jasnego i subtelnego wychowania seksualnego. W obliczu kultury, która na ogół «banalizuje» płciowość ludzką, interpretując ją i przeżywając jedynie w sposób ograniczony i zubożony, odnosząc ją jedynie do ciała i egoistycznej przyjemności, posługa wychowawcza rodziców musi skupić się zdecydowanie na kulturze życia płciowego, aby była ona prawdziwie i w pełni osobowa: płciowość jest w istocie bogactwem całej osoby - ciała, uczuć i duszy - ujawniającym swe głębokie znaczenie w doprowadzeniu osoby do złożenia daru z siebie w miłości”64.

Z tego też powodu Kościół sprzeciwia się takiej formie informowania o życiu seksualnym, które „oderwanie” jest od zasad moralnych. Zaleca zaś, aby wychowanie to było odpowiedzialne, świadome, rozsądne oraz dostosowane do czasu i wieku dzieci z zastosowaniem właściwych metod i środków ${ }^{65}$.

\section{Pedagogika miłości}

Pedagogika jako świadoma i celowa działalność wychowawcza obejmuje wszystkie obszary życia ludzkiego. Nie może pominąć więc sfery cielesnej i duchowej. Poradnictwo duchowe w miłości ułatwia rozpoznanie kierunku, w jakim są prowadzone jednostki i wspólnoty (por. 1 Tes 5, 19-22; $1 \mathrm{~J} 4,1)$. W porównaniu z pedagogiką miłość cechuje wielobarwność

\footnotetext{
i bolesnych, podjęcia konkretnych postanowień. Gra składa się ze stu sześćdziesięciu kart dla mężczyzny i stu sześćdziesięciu dla kobiety podzielonych na sześć kategorii: „Relacja”, „Seks”, „Dzieci”, „Praca”, „Teściowie”, „Pozytywy”. Na kartach znajdują się najczęściej wypowiadane przez małżonków oczekiwania i stwierdzenia. Por. Małżeńska gra. Zagraj i wygraj swoje małżeństwo, oprac. A. J. Kołodziejowie, Lublin 2013.

64 Jan Paweł II, Adhortacja apostolska Familiaris consortio, 37.

65 Por. Konferencja Episkopatu Polski, Wytyczne pastoralne do adhortacji „Amoris laetitia”, Kraków 2018.
} 
światopoglądowa i różny poziom wrażliwości, stąd niezwykłość fenomenu miłości w doświadczeniu pedagogicznym ${ }^{66}$.

Termin „pedagogika miłości” wprowadził papież Franciszek w adhortacji o miłości w rodzinie w perspektywie przygotowania narzeczonych do przyjęcia małżeństwa. Zachęca ich, by nie postrzegali „pobrania się” jako końca drogi, ale „podjęli małżeństwo jako powołanie, które wymaga stanowczej i realistycznej decyzji, aby wspólnie przejść przez wszystkie próby i chwile trudne"67. Pedagogia miłości wiąże się z kształtowaniem pełnej osobowości człowieka: „w pełni panując nad swoją wolą" (1 Kor 7,37)68. Uczucia zmysłowe (seksualne) nie mogą kierować jego życiem, bo nie są w stanie objąć całej duchowej treści i wartości oraz poprowadzić go do celu, jak to czynią rozum i wola. Nie można dać im się zbyt rozpanoszyć w naszym życiu i pozwolić opanować władze umysłowe. $Z$ drugiej strony nie da się zupełnie panować nad uczuciami. Często wybuchają one z tym większą siłą, im bardziej chce się je opanować.

Uczucia trzeba więc wychować i uduchowić. Udział uczuć w moralnym postępowaniu wiąże się z przyznaniem im właściwego miejsca w życiu. Winny być one podporządkowane rozumowi i woli, a nie jest to łatwe, o czym przekonał się sam Apostoł: „Nie rozumiem tego, co czynię. Nie czynię bowiem tego, co chcę, ale czynię to, czego nienawidzę (...). Nie czynię bowiem dobra, którego chcę, ale czynię zło, którego nie chcę" (Rz 7,15-19). Na fali uczuć, takich jak pożądanie, gniew, zazdrość lub strach, działalność rozumu i woli może być zahamowana, ale nie jest bezsilna. Arystoteles zalecał więc dyplomację. Możemy na nie oddziaływać za pomocą zmysłów poznawczych, zarówno zewnętrznych, jak i wewnętrznych, kierując wzrokiem, słuchem, dotykiem, powonieniem, odwracać się od jednego przedmiotu, a zwracać do drugiego; możemy również, choć nie jest to łatwe, kierować pamięcią i wyobraźnią i odsuwać aktem woli jedne obrazy, które się

66 Por. V. Albisetii, Wolni, aby kochać, tłum. K. Stopa, Kielce 2013; Miłość a pedagogika, red. K. Kamiński, Warszawa 2020.

67 Amoris laetitia, 211; Por. „Amoris laetitia” jako ewangelia miłości i droga do przebycia, red. G. del Missier, A. G. Hidalgo, tłum. J. Serafin, Kraków 2019.

681 Kor 7,37; J. Kochel, „Trwajcie w czystości, z wielką skromnościa”. Pawłowa interpretacja duchowej pedagogii miłości, w: Zdrowa i mocna rodzina fundamentem społeczeństwa, red. J. Stala, Kraków 2019, s. 199-212 (Family Studies, 8). 
z wyobraźni wyłaniają, i na ich miejsce wysuwać inne. Rezultatem wychowania ma być to, że człowiek może swym uczuciom zaufać ${ }^{69}$.

Papież Franciszek przekonuje: „Wychowanie uczuciowości i instynktu jest konieczne, a w tym celu czasami trzeba sobie stawiać ograniczenia. Przesada, brak kontroli, obsesja na tle jednego tylko rodzaju przyjemności, prowadzą w końcu do osłabienia i niszczą samą przyjemność, wyrządzając szkodę życiu rodziny. W gruncie rzeczy z namiętnościami można przebyć piękną drogę, co oznacza coraz większe ukierunkowanie ich na projekt daru $\mathrm{z}$ siebie i pełnej samorealizacji, który ubogaca relacje interpersonalne w obrębie rodziny. To nie oznacza rezygnacji z chwil intensywnej radości, ale podjęcie ich w splocie $\mathrm{z}$ innymi momentami wielkodusznego oddania, cierpliwej nadziei, nieuchronnego zmęczenia, wysiłku dążenia do ideału. Życie rodzinne jest tym wszystkim i zasługuje, by przeżywać je w pełni”70.

Duchowa pedagogika miłości nie umniejsza więc przyjemności, radości, namiętności i „wielkodusznego oddania” we współżyciu małżeńskim. Mężczyzna i kobieta są powołani do tego, by byli „przestrzenią”, w której przejawia się miłość Boża i rodzi życie. Natomiast zjednoczenie cielesne małżonków powinno być wyrazem takiej miłości i wzajemnego obdarowania: „My wierzymy, że Bóg miłuje radość człowieka, udzielając mu «wszystkiego obficie, byśmy z tego korzystali» (por. 1 Tm 6,17). Pozwólmy, by wypływała radość w obliczu Jego czułości, kiedy nam proponuje: «Dziecko (...), troszcz się o siebie (...). Nie pozbawiaj się dnia szczęśliwego» (Syr 14,11.14). Para małżeńska odpowiada również na wolę Bożą, wypełniając następującą zachętę biblijną: "Gdy ci się dobrze wiedzie, ciesz się z tego" (Koh 7,14). Potrzeba, aby w wolności zaakceptować fakt, że przyjemność znajduje inne formy wyrażania się w różnych momentach życia, zgodnie z potrzebami wzajemnej miłości. W tym sensie można przyjąć propozycje niektórych nauczycieli wschodnich, którzy nalegają na poszerzenie świadomości, aby nie być więźniem w doświadczeniu bardzo ograniczonym, które zamykałoby nam perspektywy. Takie poszerzenie świadomości nie jest zanegowaniem czy zniszczeniem pożądania, ale jego rozszerzeniem i udoskonaleniem"71.

Intymna bliskość oparta tylko na popędzie lub poszukiwaniu przyjemności nie doprowadza małżonków do wzajemnego poznania i harmonii

\footnotetext{
69 J. Woroniecki, Katolicka etyka wychowawcza, cz. 1, Lublin 1995, s. 97-129.

70 Franciszek, Adhortacja apostolska Amoris laetitia, 148.

71 Franciszek, Adhortacja apostolska Amoris laetitia, 149.
} 
w ich relacjach, lecz raczej do dominacji i urzeczowienia. Wspólne duchowe rozeznanie pomogą zaś odkryć właściwe narzędzia twórczych relacji. Konstruktywnym elementem tego typu pedagogiki jest np. język miłości - jeden z rodzajów komunikacji współmałżonków. Któż nie chciałby odkryć uniwersalnego języka miłości? Raz zgłębić jego zasady, a potem do końca życia używać go, by współmałżonkowie, których Bóg stawia na naszej drodze, czuli się kochani i szczęśliwi.

Dr Gary Chapman, amerykański psychoterapeuta, antropolog i lingwista, opracował teorię pięciu języków miłości, czyli różnych sposobów wyrażania i okazywania uczuć, a także ich liczne odmiany. Mąż i żona rzadko posługują się tym samym językiem miłości. Zazwyczaj używają swojego własnego języka i frustrują się, gdy współmałżonek nie rozumie tego, co chcą mu zakomunikować. Pragną, by druga strona okazywała miłość w ten sam sposób, w jaki oni ją okazuję, jednocześnie wysyłając sygnały, których on lub ona nie rozumie.

Jeśli więc:

Twoja żona woli, żebyś pomógł jej w sprzątaniu kuchni, niż zabrał ją na romantyczną kolację;

Twój mąż chciałby spędzić cały weekend w domu, a Ty chciałabyś wyjść w tym czasie ze znajomymi;

Twoja żona wszelkie komplementy przyjmuje w milczeniu, ale tryska radością, gdy kupisz jej biżuterię;

Twój mąż woli prezenty robione przez Ciebie ręcznie niż te kupione w sklepie;

Twoja żona nie chce pomocy przy obiedzie - woli, żebyśs ją przytulił, a Ty nie potrafisz tego zrozumieć najwyższy więc czas, byś przemówił w języku miłości Twojego partnera - przekonuje Chapman ${ }^{72}$.

Potrzeba poczucia bycia kochanym (szczęśliwym) jest uniwersalna i nieodzowna dla normalnego funkcjonowania w pracy, wśród znajomych i przyjaciół, w rodzinie i w małżeństwie. Małżonkowie potrzebują czuć się kochani i szczęśliwi, by osiągać swoje cele, by zmieniać się na lepsze. A ten, kto czuje się kochany, wie, że życie ma sens, odnosi sukcesy osobiste i zawodowe, jest kreatywny i przedsiębiorczy. Potrzeba więc wyrzekać się zafałszowanych postaw i relacji we wspólnym życiu (por. Mt 5,27-28). Trzeba też uwierzyć w to, że każdy z nas może stać się narzędziem w Bożych rękach, by

72 Por. G. Chapman, 5 języków miłości, tłum. J. Czernik, Kraków 2016. 
czyjeś życie nabrało sensu, by ktoś poczuł się kochany i szczęśliwy, by pokonał kryzys, który jeszcze niedawno go przygniatał. Warto zatem poszukiwać właściwych sposobów komunikacji (języka) miłości małżeńskiej, by odkryć hasło dostępu do zdrowego i szczęśliwego życia ${ }^{73}$.

Niepoślednią rolę w tego typu komunikacji pełni erotyczny wymiar miłości, który oczywiście nie zwalnia małżonków z obowiązku wychowania do czystości, będącego jednocześnie wychowywaniem ducha i wrażliwości uczuć - intymności wzajemnych relacji. W liście do Galatów św. Paweł przeciwstawia ciało duchowi: „Ciało (...) do czego innego dąży niż duch, a duch do czego innego niż ciało” (Ga 5,17). W tym fragmencie - jak przekonuje Jan Paweł II - nie chodzi o przeciwstawienie ciała jako materii duchowi czy duszy i zwrócenie uwagi na istnienie w nas tych dwóch różnych od siebie substancji czy elementów. To napięcie istnieje tylko wewnątrz człowieka, w jego sercu. Ciało w teologii św. Pawła oznacza człowieka, którego serce jest poddane światu, człowieka żyjącego w obrębie tych wartości, które narzuca mu świat. Człowiek cielesny żyje na przeciwnym biegunie w stosunku do tego, „czego chce Duch” (por. Ga 5,16-26). Święty Paweł pisze o rozdarciu, które w nim jest - o złu, które człowiek czyni, choć tego nie chce, i o niemożliwości czynienia dobra, którego pragnie (por. Rz 7,14-19). Napięcie pomiędzy „ciałem” a „duchem” w człowieku wyraża się jako „przesilanie się” dobra i zła w jego sercu. W ostateczności chodzi o odkrycie nowego prawa - Prawa wolności (Ga 5,13-15). Nieodzowna jest zatem pedagogia miłości, czyli stałe kierownictwo duchowe w małżeństwie i rodzinie ${ }^{74}$.

Obok inspiracji biblijnych na temat tego typu pedagogiki miłości wypowiada się Kościół w swoim oficjalnym nauczaniu. Jan Paweł II pisał np. o wychowaniu do czystości jako cnoty, która „doprowadza osobę do prawdziwej dojrzałości i uzdalnia ją do szanowania i rozwijania «oblubieńczego sensu» ciała"75. Cennych wskazań na temat takiej pedagogii warto też szukać w dokumencie Papieskiej Rady ds. Rodziny Wychowanie do czystej miłości. Życie w czystości jako stała postawa wobec innych osób w dużym stopniu zależy od sposobu panowania nad spontanicznymi odruchami i uczuciami, z których jedne trzeba rozwijać, a inne kontrolować. Jan Paweł II

\footnotetext{
73 Por. J. C. Almeida, Pięć sekretów miłości, tłum. G. Borowski, Kraków 2017.

74 J. Goleń, Kierownictwo duchowe małżonków, w: Duszpasterstwo rodzin. Refleksja naukowa i działalność pastoralna, red. J. Goleń, R. Kamiński, G. Pyźlak, Lublin 2013, s. 407-418.

75 Jan Paweł II, Adhortacja apostolska Familiaris consortio, 37.
} 
- posługując się językiem św. Pawła - pisze o czystości jako „powstrzymywaniu namiętności, czyli „utrzymywaniu ciała we czci i świętości” (1 Tes 4, 7-8). Chodzi więc o opanowanie, wstrzemięźliwość (łac. temperantia) oraz świadomy wybór.

Podstawowym chrześcijańskim środkiem wychowawczym w dziedzinie miłości jest czystość, która integruje biologiczne, psychiczne i duchowe wymiary seksualności ludzkiej. Czystość (łac. conscius - „świadomy”) to cnota, z pomocą której „zdolny do namiętności człowiek świadomie i zdecydowanie rezerwuje swoją aktywność erotyczną dla miłości i przeciwstawia się innym pokusom seksualnego podniecenia i zaspokojenia czy używania innych osób dla własnego zaspokojenia"76. Papież w swoim dziele Miłość i odpowiedzialność przeprowadził swego rodzaju rehabilitację cnoty czystości. Rehabilitacja przywraca dobre imię. Czy cnota czystości straciła dobre imię - pyta Wojtyła? „Zdaje się, że jeśli której cnocie, to przede wszystkim czystości odebrano na drodze resentymentu ${ }^{77}$ wiele praw do duszy ludzkiej, w woli i sercu człowieka. Stworzono przeciw niej całą argumentację, starając się wykazać, że nie jest ona pożyteczna dla człowieka, lecz szkodliwa"78. Wojtyła przeciwstawia się różnorodnym zastrzeżeniom natury rzekomo higienicznej i lekarskiej skierowanej przeciw czystości i opanowaniu seksualnemu, które przytaczają argumenty za tym, że owszem - czystość ma rację bytu, lecz poza miłością mężczyzny i kobiety, w „miłości musi ustąpić”. Wojtyła przekonuje, że kiedy człowiek uzna pełną prawdę o miłości kobiety i mężczyzny, wtedy też dostrzeże wartość czystości. Czystości nie sposób pojąć bez cnoty miłości. Ma ona za zadanie wyzwalać miłość od postawy użycia. Dlatego czystość definiuje on jako jasną („przejrzystą”) postawę

76 Jan Paweł II, „Mężczyzną i niewiastą stworzył ich”, dz. cyt., s. 214-218.

77 „Resentyment - zdaniem K. Wojtyły - polega na błędnym, wypaczonym stosunku do wartości. Jest to brak obiektywizmu w ocenie i wartościowaniu, a źródła jego leżą w słabości woli. Chodzi o to, że wyższa wartość domaga się większego wysiłku woli, jeśli chcemy ją osiągnąć lub zrealizować. Aby więc subiektywnie zwolnić się od tego wysiłku, aby przed samym sobą usprawiedliwić brak tej wartości, pomniejszamy jej znaczenie, odmawiamy jej tego, co w rzeczywistości jej przysługuje, widzimy w niej wręcz jakieś zło, choć obiektywizm zobowiązuje do uznania dobra (...). Resentyment idzie jednak dalej: nie tylko fałszuje obraz dobra, ale deprecjonuje to, co powinno zasługiwać na uznanie, aby człowiek nie musiał z trudem podciągać siebie do prawdziwego dobra, aby mógł «bezpiecznie» uznawać za dobro to tylko, co jemu odpowiada, co dla niego wygodne. Resentyment mieści się w mentalności subiektywnej: przyjemność zastępuje tu nadrzędną wartość”. Por. K. Wojtyła, Miłość i odpowiedzialność, dz. cyt., 129n.

78 Jan Paweł II, „Mężczyzną i niewiastą stworzył ich”, dz. cyt., s. 130. 
wobec osoby odmiennej płci. „Być czystym znaczy: mieć «przejrzystość» wnętrza, bez której miłość nie jest sobą, nie jest bowiem sobą tak długo, jak długo chęć «używania» nie została podporządkowana gotowości «miłowania» w każdej sytuacji”79. W takiej relacji przyszły papież widzi porządek, równowagę, opanowanie i harmonię $\mathrm{w}$ zaspokajaniu popędów psychofizycznych i psychosomatycznych ${ }^{80}$.

Podobne spojrzenie na cnotę czystości w małżeństwie i rodzinie prezentował kard. Joseph Ratzinger, który jako arcybiskup Monachium poświęcił jeden $\mathrm{z}$ swoich listów pasterskich tematyce małżeństwa i rodziny. Przekonywał, że od podejścia, jakie mamy do małżeństwa i rodziny, zależą nasza teraźniejszość i przyszłość. Mężczyzna i kobieta według Biblii są tej samej natury i równi w godności. „Cnota czystości nie prowadzi do negacji własnej cielesności, lecz jej istotą jest doprowadzić zdolność kochania do jej autentycznej wielkości i w pełni zakorzenić seksualność w godności człowieka. Szczytem wolności jest ludzka zdolność do definitywności własnych decyzji. Oddanie drugiemu człowiekowi, wierność wobec niego nie jest przeciwieństwem wolności, lecz jej prawdziwym początkiem. Dziecko nie jest zagrożeniem, umniejszeniem wolności, ograniczeniem samorealizacji. Przyszłość z pewnością będzie zagrożona, jeśli w obawie przed samoograniczeniem zanegujemy jedyną siłę, która może zapewnić nam tę przyszłość - dzieci”»1.

W teologii/pedagogii ciała ważną rolę odgrywa również profilaktyka spojrzeń, dotyku oraz tzw. „terapia wstydliwości”. Wstyd jest reakcją obronną: broni godności i intymności - „obrazu i podobieństwa Bożego” $(\operatorname{Rdz} 1,27)$. Koncepcję tę rozwijali etycy i teologowie duchowości ${ }^{82}$. Czystość, nawiązując do przesłania biblijnego, oznacza harmonię i integrację.

79 Jan Paweł II, „Mężczyzną i niewiastą stworzył ich”, dz. cyt., s. 153.

80 W. Bołoz, Integrować swoją płciowość, aby kochać, w: Przygotowanie do życia w rodzinie, red. K. Ostrowska, M. Ryś, Warszawa 1997, s. 135-144; B. J. Groeschel, O odwadze życia w czystości, tłum. J. Wocial, Warszawa 1998; s. 130-140; S. Morgalla, Miłość piękna, miłość czysta, „Życie Duchowe” 75 (2013), s. 35-40.

81 W taki sposób streszcza treść listu biograf Ratzingera - Elio Guerriero - powołując się na źródła: Joseph Ratzinger und das Erzbistum München und Freising. Dokumente und Bilder aus kirklichen Archiven. Beiträge und Erinnerungen, Hrsg. P. Pfister, Regensburg 2006; por. E. Guerriero, Świadek prawdy. Biografia Benedykta XVI, tłum. J. Tomaszek, Kraków 2018, s. 220.

82 K. Wojtyła, Miłość i odpowiedzialność, dz. cyt., s. 156-172; K. Grzywocz, Zawstydzone ciało, „Życie Duchowe” 12 (2005), nr 42, s. 28-34. 
Człowiek o „czystym sercu” to osoba zintegrowana, która harmonijnie łączy wszystkie obszary swojego człowieczeństwa (fizyczny, psychiczny, duchowy). Ta harmonia wewnętrzna służy budowaniu szczęśliwych relacji - dobrych ludzkich więzi. Chrześcijańskie ujęcie wychowania do życia w małżeństwie i rodzinie przyjmuje więc za podstawę koncepcję człowiek jako osoby w jego cielesno-duchowej strukturze.

Jasna postawa i świadomy wybór, które poprzedzają wychowanie do czystości i odpowiedzialności współmałżonków, są nieodłącznie związane $\mathrm{z}$ obowiązkiem rozwijania (praktykowania) wszystkich innych cnót, w szczególności miłości, która jest „więzią doskonałości” (por. Kol 3,14; 1 Kor 13,13). W wychowaniu do miłości konieczne jest panowanie nad sobą, które z kolei zakłada pewne sprawności, nazywane też „młodszymi siostrami czystości", jak: wstydliwość, opanowanie, szacunek dla samego siebie i innych; otwarcie, czułość i wrażliwość na życie drugiego.

W tego typu formacji trzeba wyróżnić kilka elementów:

- miłość małżeńską jako „powołanie”, „zjednoczenie osób”, „dar z samego siebie",

- kształtowanie wstydliwości i skromności - troskę o intymność,

- autentyczny dialog i kulturę spotkania,

- „kulturę miłowania”"83,

- odpowiedzialne rodzicielstwo - wspaniałomyślne otwarcie na życie,

- budowanie więzi osobowych,

- wspólną modlitwę i życie sakramentalne,

- panowanie nad samym sobą/samowychowanie ${ }^{84}$.

Z perspektywy pastoralnej podstawowe założenia wychowania do czystej i odpowiedzialnej miłości dobrze odczytały Ruch Czystych Serc (RCS) i Ruch Czystych Serc Małżeństw (RCSM) wspierane przez międzynarodowe pismo „Miłujcie się!". W Polsce Ruch Czystych Serc odszedł od założeń

83 O „kulturze miłowania” Wojtyła pisał w kontekście odpowiedzialnego rodzicielstwa, czyli dostosowania współżycia seksualnego do celu, jakim jest dobro osoby, i opanowania uczuć erotycznych ze względu na wymóg odpowiedzialności za drugiego człowieka: „Wymaga to też gruntownej kultury osoby i «kultury miłowania». Autentyczna wstrzemięźliwość małżeńska wyrasta ze wstydu, który reaguje negatywnie na każdy przejaw «używania» osoby, ale $\mathrm{i}$ - z drugiej strony - reakcja wstydu okazuje się tym silniejsza, im bardziej autentyczna jest wstrzemięźliwość, a wraz z nią «kultura osoby» i «kultura miłowania». Por. K. Wojtyła, Miłość i odpowiedzialność, dz. cyt., 208n.

84 Por. A. Sarmiento, Małżeństwo chrześcijańskie. Podręcznik teologii małżeństwa i rodziny, tłum. P. Rak, Kraków 2002; Y. Semen, Seksualność według Jana Pawła II, dz. cyt. 
wypracowanych w USA (ruch społecznej abstynencji), a oparł się na „teologii/pedagogii ciała" Jana Pawła II oraz wskazaniach Papieskiej Rady ds. Rodziny ${ }^{85}$. Opracowane zostały również ogólnopolski program i podręcznik formacyjny dla młodzieży Droga czystej miłości ${ }^{86}$ oraz materiały formacyjne dla małżonków Duchowa pedagogia miłości ${ }^{87}$. „Tak” dla edukacji seksualnej jest więc pozytywnym (duchowym) przesłaniem rozwijanym w ramach katolickiej etyki wychowania ${ }^{88}$.

Miłość czysta i odpowiedzialna jako dar i zadanie nie może istnieć bez umiejętności wyrzeczenia, ofiary czy oczekiwania, dlatego tak ważne jest wychowanie i samowychowanie. Nie jest to zadanie na wolny czas ani dodatek do innych zajęć. Jest to podstawowe wyzwanie, wręcz bitwa, w której należy odnieść zwycięstwo i która wymaga ciągłego wysiłku i ogromnej energii ze strony współpracujących ze sobą rodziców, wychowawców i ludzi młodych. Fundamentem duchowej pedagogii miłości jest zachowywanie Bożych przykazań, które są gwarancją szczęścia małżeńskiego (rodzinnego). Celem takiej pedagogii jest wychowanie siebie i innych, by być takim, jakim Bóg chce, byśmy byli, tzn. zdolnym do miłości, do zapierania się siebie, do służby wbrew negatywnym uczuciom.

\section{Podsumowanie}

Właściwa pedagogika miłości to złożony proces wychowawczy, którym interesują się nie tylko młodzi ludzie przygotowujący się do zawarcia sakramentalnego związku małżeńskiego. Zainteresowane są nią również współczesne nauki, np. antropologia, teologia, pedagogika. Jeśli seksualność wpisana jest w naturę ludzką i stanowi fundamentalną misję człowieka - „przekazywanie życia” - to sama w sobie jest piękna i dobra, przynosi radość i szczęście. Stąd też Kościół zawsze promował pozytywne duchowe przesłanie wychowania do życia w rodzinie i małżeństwie. Świat, który nas otacza, intuicyjnie szuka na nowo sensu miłości, jej prawdziwego znaczenia.

\footnotetext{
85 Por. Papieska Rada ds. Rodziny. Wychowanie do czystej miłości. Wskazania dla wychowania $w$ rodzinie, Kraków 2011.

86 Por. M. Kwiek, I. Nowak, Droga czystej miłości: podręcznikformacyjny, Poznań 2010.

87 Por. J. Kochel, Duchowa pedagogia miłości, dz. cyt.

88 Por. Franciszek, Adhortacja apostolska Amoris laetitia, 280-290.
} 
Pośród młodzieży upowszechnia się pytanie (wołanie) Biedaczyny z Asyżu, który pragnął iść na cały świat i krzyczeć, budząc ludzi z uśpienia: „Dlaczego miłość nie jest kochana?”. Ideał miłości czystej i odpowiedzialnej jest wyzwaniem dla każdego, również dla młodych zakochanych i połączonych sakramentalnym węzłem. Dar z siebie, czystość serca oraz wzajemna modlitwa mogą pomóc im odkryć w sobie taką wiedzę, która odsłoni wartość miłości we wszystkich jej odcieniach i barwach, również w tej niezwykle intymnej i czułej sferze, jaką jest seksualność.

Wspólnota Ruchu Czystych Serc Małżeństw (RCSM), jako kontynuacja formacji Ruchu Czystych Serc (RCS), skierowana jest do małżonków sakramentalnych i wciela w życie teologię/pedagogię ciała, pedagogikę nowego człowieka oraz "kulturę miłowania” - miłość odpowiedzialną i czystą. Aby włączyć się w Ruch Czystych Serc Małżeństw, wystarczy pragnienie pójścia przez życie z Tym, który jest Miłością (por. $1 \mathrm{~J}$ 4,16). Istotna jest stała formacja intelektualna, moralna i duchowa małżeńska i rodzinna, którą RCSM stopniowo i konsekwentnie rozwija, np. przez praktykowanie sakramentalnego życia małżonków oraz wspólne odmawianie Modlitwy zawierzenia $^{89}$ : „Panie Jezu, dziękujemy Ci, że ukochałeś nas miłością bez granic, nie wahając się nawet oddać życie za nas. Dziękujemy Ci za to, że Twoja miłość chroni nas od zła, podnosi nas z największych upadków i leczy nasze najboleśniejsze rany. Dziękujemy Ci za Twoją obecność w sakramencie małżeństwa i za to, że u Ciebie zawsze możemy znaleźć lekarstwo na każde zło i siłę do pokonywania wszelkich trudności i kryzysów. Oddajemy Ci naszą pamięć, rozum, wolę, dusze i ciała wraz z naszą płciowością. Przyrzekamy codziennie spotykać się z Tobą na wspólnej modlitwie i w lekturze Pisma św., w częstym przyjmowaniu Komunii św. i w adoracji Najświętszego Sakramentu. Postanawiamy regularnie przystępować do sakramentu pojednania, nie ulegać zniechęceniu i natychmiast podnosić się z każdego grzechu. Postanawiamy nie kupować, nie czytać i nie oglądać czasopism, programów ani filmów o treściach pornograficznych. Przyrzekamy nie używać żadnych środków antykoncepcyjnych i rezygnujemy z samej postawy antykoncepcyjnej. Przyrzekamy być zawsze gotowymi na przyjęcie każdego dziecka, które Ty, Panie, pragniesz powołać do istnienia. Pragniemy być dla nich

89 Warunki przystąpienia do RCSM. Por. www.archiwum.milujciesie.org.pl/pg/pl/ inicjatywy_ms/ruch_czystych_serc_malzenstw/warunki_przystapienia_do_rcsm.html (24.02.2020). 
dobrymi wychowawcami, własną postawą i własnym świadectwem ukazującymi drogę do Ciebie. Panie Jezu, ucz nas systematycznej pracy nad sobą, umiejętności kontrolowania naszych pobudzeń seksualnych i emocji. Prosimy Cię o odwagę w codziennym przeciwstawianiu się złu, abyśmy unikali wszystkiego, co uzależnia i zniewala, a przede wszystkim narkotyków, alkoholu i nikotyny. Ucz nas tak postępować, aby w naszym życiu najważniejsza była miłość. Maryjo, Matko nasza, prowadź nas drogami wiary do samego źródła miłości - do Jezusa. Za św. Janem Pawłem II pragniemy całkowicie zawierzyć się Tobie: «Totus Tuus, Maryjo»! W Twoim Niepokalanym Sercu składamy całych siebie, wszystko, czym jesteśmy, każdy nasz krok, każdą chwilę naszego życia. Amen!”.

\section{Bibliografia}

Albisetii V., Wolni, aby kochać, tłum. Krzysztof Stopa, Kielce 2013.

Almeida J. C., Pięć sekretów miłości, tłum. G. Borowski, Kraków 2017.

"Amoris laetitia" jako ewangelia mitości i droga do przebycia, red. G. del Missier, A. G. Fidalgo, tłum. J. Serafin, Kraków 2019.

Ange D., Twoje ciało stworzone do życia, tłum. J. Pleciński, Poznań, 1996.

Augustyn J., Integracja seksualna. Przewodnik w poznawaniu i kształtowaniu własnej seksualności, Kraków 1995 (2019)6.

Babik M., Słownik biblijny. Małżeństwo - rodzina - seksualność, Kraków 2009.

Benedykt XVI, Adhortacja apostolska Verbum Domini, Kraków 2010.

Benedykt XVI, Encyklika Deus caritas est, Poznań 2006.

Bołoz W., Integrować swoja ptciowość, aby kochać, w: Przygotowanie do życia w rodzinie, red. K. Ostrowska, M. Ryś, Warszawa 1997, s. 135-144.

Braun-Gałkowska M., Miłość aktywna. Psychiczne uwarunkowania powodzenia w małżeństwie, Warszawa 1980.

Bujak A., Rożek M., Wojtyła, Wrocław 1997.

Chapman G., 5 języków miłości, tłum. J. Czernik, Kraków 2016.

Chmiel J., Siedem spojrzeń na płciowość w Biblii, „Ruch Biblijny i Liturgiczny" 50/1 (1997), s. 28-35. 
Coogan M. D., Bóg i seks. Co naprawdę mówi Biblia, tłum. A. Onysymow, Warszawa 2011.

Dillow J. i L., Pintus P. i L., Rozpalona miłość. Jak rozwijać małżeńską intymność w oparciu o „Pieśń nad pieśniami” Salomona, tłum. G. Kożusznik, Ustroń 2005.

Dziewiecki M., Problemy z seksualnościq. Odpowiedzi na dylematy młodych chrześcijan, Kraków 2011.

Evert J., Teologia jej ciała / teologia jego ciała, tłum. J. Kurdziel, Kraków 2014.

Franciszek, Posynodalna adhortacja apostolska Amoris laetitia, Kraków 2016.

Fraling B., Sexualethik. Ein Versuch Aus Christlicher Sicht, Paderborn 1995.

Frossard A., «Nie lękajcie się!». Rozmowy z Janem Pawłem II, tłum. A. Turowiczowa, Watykan 1982.

Gajdowie M. i M., Grzywocz K., Otwarci na miłość. Jak pokonać bariery?, audiobook MP3, Wrocław 2018.

Galarowicz J., Człowiek jest osobą. Podstawy antropologii filozoficznej Karola Wojtyly, Kraków 1994.

Gałuszka P. S., Karol Wojtyła e „Humanae vitae”. Il contributo dell'Arcivescovo di Cracovia e del gruppo del teologi polacchi allenciclica do Paolo VI, Siena 2018.

Giddens A., Przemiany intymności. Seksualność, miłość i erotyzm we wspótczesnych społeczeństwach, tłum. A. Szulżycka, Warszawa 2006.

Goleń J., Kierownictwo duchowe matżonków, w: Duszpasterstwo rodzin. Refleksja naukowa i działalność pastoralna, red. J. Goleń, R. Kamiński, G. Pyźlak, Lublin 2013, s. 407-418.

Goleń J., Wychowanie seksualne w rodzinie. Studium pastoralne, Rzeszów 2006.

Groeschel B. J., O odwadze życia w czystości, tłum. J. Wocial, Warszawa 1998.

Góralczyk P., Wychowawcza etyka seksualna, Ząbki 2000.

Grygiel S., Na ścieżkach prawdy. Rozmawiając z Janem Pawłem II, Poznań 2013.

Grzywocz K., Zawstydzone ciało, „Życie Duchowe” 12 (2005), nr 42, s. 28-34.

Guerriero E., Świadek prawdy. Biografia Benedykta XVI, tłum. J. Tomaszek, Kraków 2018.

Izdebski Z., Pedagogika seksualna, w: Encyklopedia pedagogiczna XXI wieku, red. T. Pilch, t. 4, Warszawa 2005, s. 252-257. 
Jan Paweł II, Adhortacja apostolska Familiaris consortio, Watykan 1981.

Jan Paweł II, Encyklika Dives in misericordia, Poznań 1980.

Jan Paweł II, Encyklika Veritatis splendor, Kraków 1993.

Jan Paweł II, „Mężczyzna i niewiasta stworzył ich”. Odkupienie ciała a sakramentalność małżeństwa, Watykan 1986.

Jaromin J., Analiza lingwistyczna „Hymnu o miłości” (1 Kor 13,1-13), w: Jak śmierć potężna jest miłość. Księga pamiątkowa ku czci Księdza Profesora Juliana Warzechy SAC (1944-2009), red. W. Chrostowski, Ząbki 2009.

Karras Mazo R., Seksualność w średniowiecznej Europie, tłum. A. Bugaj, Warszawa 2012.

Kochel J., Duchowa pedagogia miłości, Poznań 2018.

Kochel J., „Trwajcie w czystości, z wielka skromnościa”. Pawłowa interpretacja duchowej pedagogii miłości, w: Zdrowa i mocna rodzina fundamentem społeczeństwa, red. J. Stala, Kraków 2019, s. 199-212 (Family Studies, 8).

Kochel J., Wprowadzenie do antropologii pedagogicznej. W kregu pedagogiki katolickiej, Opole 2018.

Komorowska-Pudło M., Seksualność młodzieży XX i XXI wieku, Kraków 2013.

Konferencja Episkopatu Polski, Wytyczne pastoralne do adhortacji „Amoris laetitia”, Kraków 2018.

Kopycki P., Elementarz teologii ciała według Jana Pawła II, Częstochowa 2013.

Kościót a problemy etyki seksualnej. Komentarz do Deklaracji „Persona humana”, tłum. A. Szymanowski, Warszawa 1987.

Kuby G., Globalna rewolucja seksualna. Likwidacja wolności w imię wolności, Kraków 2013.

Kuby G., Rewolucja genderowa. Nowa ideologia seksualności, Kraków 2007.

Kułaczkowski J., Biblijne zasady wychowania rodzinnego w świetle Ksiegi Syracha, Rzeszów 1998.

Kupczak J., Dar i komunia. Teologia ciała w ujęciu Jana Pawła II, Kraków 2006.

Kwiek M., Nowak I., Droga czystej miłości: podręcznik formacyjny, Poznań 2010.

Lis T., Zarys antropologii teologicznej Jana Pawła II, „Warszawskie Studia Teologiczne" 17 (2004), s. 109-166. 
Lemański J. Księga Rodzaju. Rozdzialy 1 - 11, Częstochowa 2013 (Nowy Komentarz Biblijny. Stary Testament I/1).

Majdański K., W służbie prawdzie o rodzinie. Prawda o człowieku, rodzinie i cywilizacji, red. B. Bassa, E. Osewska, J. Stala, Kraków 2019.

Małżeńska gra. Zagraj i wygraj swoje małżeństwo, oprac. A. J. Kołodziejowie, Lublin 2013.

Marcol A., Etyka życia seksualnego, Opole 1995.

Marczewski R., Teologia ciała Jana Pawła II. W praktyce amerykańskiego Kościoła, Kraków 2015.

Mazurkiewicz P., Dwie wieże i minaret, Warszawa 2017.

McDowell J., Mity edukacji seksualnej, tłum. B. Kośmider, Warszawa 2000.

Meissner K., Jeden plus jeden to jedność, audiobook MP3, Poznań 2017.

Meissner K., Płciowość i czystość. Z problematyki życia seksualnego, Poznań 2004.

Meissner K., Psychologia płciowości, audiobook MP3, Poznań 2017.

Metzger B. M., Coogan M. D., Słownik wiedzy biblijnej, Warszawa 20044.

Miąso J., Antropologia, wychowanie, miłość. Zarys antropologii wychowania Jana Pawła II, Rzeszów 2014.

Miłość a pedagogika, red. K. Kamiński, Warszawa 2020.

Miłość, płciowość, płodność. Aktualne problemy etyki seksualnej, red. P. Morciniec, Opole 2007 (Opolska Biblioteka Teologiczna, 99).

Morgalla S., Miłość piękna, miłość czysta, „Życie Duchowe” 75 (2013), s. $35-40$.

Mroczkowski I., Osoba i cielesność. Moralne aspekty teologii ciała, Płock 20082.

Nagórny J., Cywilizacja miłości wobec współczesnych zagrożeń cywilizacyjnych, w: Przyszłość cywilizacji Zachodu, red. P. Jaroszyński i in., Lublin 2003 s. $57-89$.

Nagórny J., Płciowość - miłość - rodzina, Lublin 2009.

Najda A., Stworzeni z miłości: wokót Jana Pawła II teologii ciała, Warszawa 2010.

Nietzsche F., Jenseits von Gut und Böse, München 1954.

Nosowski Z., All You Need is Sex? Jak zmienia się wspótczesne rozumienie erotyki?, „Więź" 7-8 (597) 2008, s. 72-82.

Nowak M., Podstawy pedagogiki otwartej. Ujęcie dynamiczne w inspiracji chrześcijańskiej, Lublin 1999. 
Papieska Rada ds. Rodziny, Ludzka płciowość, prawda i znaczenie. Wskazania dla wychowania $w$ rodzinie, www.kodr.pl/wp-content/uploads/2018/10ludzka_plciowosc_prawda_i_znaczenie.pfd (10.03.2020).

Papieska Rada ds. Rodziny. Wychowanie do czystej miłości. Wskazania dla wychowania w rodzinie, Kraków 2011.

Paweł VI, Encyklika Humanae vitae, Szczecin 1986.

Paweł VI, Deklaracja o niektórych zagadnieniach etyki seksualnej «Persona humana», „Acta Apostolicae Sedis” 68 (1976) 77-96.

Pearl M., Seks (nie)zakazany owoc Biblii, tłum. G. Ciecieląg, Warszawa 2011. Pilśniak M., Krótka kołdra. O dialogu matżeńskim, Poznań 2010.

Pontificia Commissione Biblica, Che cosa è l'uomo? (Sal 8,5). Un itinerario di antopologia biblica, Città del Vaticano 2019.

Półtawska W., Eros et iuventus!, Częstochowa 2009.

Półtawska W., Przygotowanie do małżeństwa, Kraków 2002.

Primoratz I., Filozofia seksu, tłum. J. Klimczyk, Warszawa 2012.

Przymierze małżeńskie, red. S. Bednarowicz, Poznań 2014.

Ranke-Heinemann U., Eunuchen für das Himmelreich. Katholische Kirche und Sexualität von Jesus bis Benedikt XVI, Hamburg 1988 (wyd. pol. Eunuchy do raju. Kościół katolicki a seksualizm, tłum. M. Zeller, Gdynia 2003 oraz Ranke-Heinemann U., Seks. Odwieczny problem Kościoła, tłum. S. Lipnicki, U. Szymanderska, M. Zeller, Warszawa 2016).

Ranke-Heinemann U., Neinund Amen. Mein Abschied vom traditionellen Christentum, Hamburg 1992 (wyd. pol. Nie i amen, tłum. K. Teoplitz, Gdynia 1994).

Ravasi G., Pieśń nad pieśniami... jak pieczęć na twym sercu, tłum. K. Stopa, Kraków 2005.

Ravasi G., Psalmy, cz. 2, tłum. K. Stopa, Kraków 2007.

Rolheiser R., Duchowość seksualności, tłum. K. Tybinka, Kraków 2013.

Rosik M., Pierwszy List do Koryntian, Częstochowa 2009 (Nowy Komentarz Biblijny. Nowy Testament, VII).

Rupnik M. I., Averincev S., Adam i jego żebro. Duchowość miłości małżeńskiej, tłum. B. Żukowska, Kraków 2009.

Sarmiento A., Małżeństwo chrześcijańskie. Podręcznik teologii małżeństwa i rodziny, tłum. P. Rak, Kraków 2002.

Scruton R., Pożądanie. Filozofia moralna życia erotycznego, tłum. T. Kuniński, Kraków 2009. 
Semen Y., Duchowość małżeńska według Jana Pawła II, tłum. S. Filipowicz, Poznań 2011.

Semen Y., Seksualność według Jana Pawła II, tłum. Z. Denkowska, J. Urbaniak, Poznań 2008.

Siemion M., Seks według Jana Pawła II cię wyzwoli, Kraków 2016.

Seremak W., Cywilizacja miłości, w: Leksykon duchowości katolickiej, Lublin-Kraków 2002, s. 154-156.

Skrzypczak R., Bitwa o seksualność, www.fronda.pl/a/ks-prof-robert-skrzypczak-bitwa-o-seksualnosc, 106002.html/ (23.03.2020).

Skrzypczak R., Karol Wojtyły na Soborze Watykańskim II. Zbiór wystąpień, Warszawa 2011.

Skrzypczak R., Wiara i seks. Jan Paweł II o małżństwie i rodzinie, Kraków 2015.

Sławiński S., Wychowanie seksualne czy wychowanie do miłości, w: Wychowanie - potrzeba dziecka - zadanie domu i szkoły, red. E. Ozimek, Poznań 1999, s. 51-59.

Styczeń T., Comprendere l'uomo. La visione antropologica di Karol Wojtyła, Roma 2005.

Sobór Watykański II, Konstytucja dogmatyczna o Kościele Lumen gentium, w: Sobór Watykański II, Konstytucje - dekrety - deklaracje, Poznań 2002.

Miłość i seks w kulturach Wschodu starożytnego, red. K. Szarzyńska K. i in., Warszawa 1996.

Ślipko T., Przedmałżeńska etyka seksualna, Kraków 2012.

Tannahill R., Historia seksu, tłum. G. Woźniak, Warszawa 2013.

Tchorzewski de A. M., Samowychowanie droga osobistego rozwoju człowieka, w: Septuaginta pedagogiczno-katechetyczna. Ksiega jubileuszowa dedykowana Księdzu Profesorowi Zbigniewowi Markowi SJ w siedemdziesiąta rocznicę urodzin, red. A. Walulik, J. Mółka, Kraków 2017, s. 193-208.

Uwolnić się od pornografii. Program „Wolni, aby kochać”, red. E. Jacquinet, tłum. A. Muszala, Kraków 2020.

Weigel G., Listy do młodego katolika, tłum. J. Franczak, Kraków 2006.

West Ch., Teologia ciała dla początkujacych. Podstawy rewolucji seksualnej Jana Pawła II, tłum. M. i J. Kaniewscy, Warszawa 2009.

Wędrując ku dorosłości. Wychowanie do życia w rodzinie. Program nauczania, red. T. Król, Kraków 2017.

Wiśniewska-Roszkowska K., Seks i moralność, Warszawa 1988. 
Wiśniewski K., Boski rodowód miłości erotycznej. Teologiczna refleksja o Trój-

cy Świętej i człowieku, „Collectanea Theologica” 76 (2006) nr 4, s. 47-79.

Wojciechowski M., Etyka Biblii, Kraków 2009.

Wojciechowski M., Księga Tobiasza, czyli Tobita, Częstochowa 2005 (Nowy Komentarz Biblijny. Stary Testament XII).

Wojtyła K., Miłość i odpowiedzialność, Lublin 1986.

Wojtyła K., „Osoba i czyn” oraz inne studia antropologiczne, Lublin 1994.

Wojciszke M. B., Psychologia miłości. Namiętność, intymność, zaangażowanie, Gdańsk 2000.

Wołochowiczowie M. i P., Seks po chrześcijańsku, Częstochowa 2012.

Woroniecki J., Katolicka etyka wychowawcza, cz. 1-3, Lublin 1995.

Wychowanie do czystości - utopia czy zadanie, red. J. Kochel, Opole 2011.

Wychowanie seksualne w rodzinie i szkole, red. Glombik, Opole 2010.

Zanim wybierzesz... Przygotowanie do życia $w$ rodzinie. Podstawy wychowania seksualnego, red. M. i W. Grabowscy, A. i M. Niemyscy, M. i P. Wołochowiczowie, Warszawa 19992.

Zatorski W., Kryzys matżeństwa?, Kraków 2018.

Zwoliński A., Seksualność w relacjach społecznych, Kraków 2006. 